\title{
Bioenergy Potential Based on Vinasse From Ethanol Industrial Waste to Green Energy Sustainability
}

\author{
Nani Harihastuti, ${ }^{1, *}$, and Bekti Marlena ${ }^{1}$ \\ ${ }^{1}$ Centre of Industrial Pollution Prevention Technology, Jl. Ki Mangunsarkoro No. 6 Semarang 50136 - Indonesia
}

\begin{abstract}
The waste water from alcohol industry is called vinasse has a high organic content, with BOD5 $=109.038 \mathrm{mg} / \mathrm{l}, \mathrm{COD}=353.797 \mathrm{mg} / 1$ and $\mathrm{TSS}=7200 \mathrm{mg} / 1, \mathrm{pH} 4-5$ with a temperature of around 40$50^{\circ} \mathrm{C}$. The current treatment of alcohol waste water, most still using facultative anaerobic technology with open ponds that are only covered with HDPE plastics. This technology produces less optimal biogas and has a weakness that is the hydraulic residence time (HRT) for long (40-50 days), wide land needs, low COD reduction efficiency as well as high risk of fire and leakage of biogas release high to trigger the occurrence of greenhouse gas and global warming effects. Development of technology with innovation reactor integration model Fixed Dome-Hybrid Anaerobic Filter aims to expand the contact area between the substrate and microbial with modification of the substrate flow system and the area of the filter and integrate with the gas accumulator. The design of this Fixed Dome-Hybrid Anaerobic filter integration model technology, has the advantage of producing optimal bioenergy with $\mathrm{CH} 4$ more than $50 \%$ content with decrease of COD more than $85 \%$ and hydraulic residence time of about 10 (ten) days, bioenergy result is renewable energy made from raw material vinasse from alcohol industrial waste which can be utilized for fuel substitution on the distillation process or boiler process of the industry in a sustainable and cleaner environment.
\end{abstract}

\section{Introduction}

Indonesia will face the threat of energy crisis in 20202030 [1]. One sector that will be affected by the energy crisis is industrial sector. The industrial sector that has been rely on fossil fuel sources must seek alternative energy sources such as renewable energy.

The Ministry of Industry ensuring the sustainability of industrial development through savings and energy diversification policies and greater attention to the development of renewable energy sources through Indonesia Government Regulation No. 14 year 2015 on the National Industrial Development Master Plan (RIPIN) of 2015-2035. Development of renewable energy sources is one of the government policies in the provision of energy needs for industry [2]

One potential renewable energy sources that has not been explored to its full potential is the energy potential from waste of alcohol industry. According to the Indonesian Ethanol Association (ASENDO), there are 16 large industries and some alcohol centers of $150-200$ Small-Medium Enterprises (SMEs). The problem faced by both large and SMEs was environmental pollution from wastewater that is not managed properly.

Some researchers have proposed some treatments of this wastewater [3-8]. Generally anaerobic treatments [910] is chosen to treat this wastewater, especially anaerobic membrane [11], UASB [12-13], anaerobic Baffled Reactor [14], Anaerobic Sequencing Baffled
Reactor [15]. Nevertheless, there are also several studies using ultra filtration [16] and catalytic thermolysis [17].

Large scale alcohol industries in Indonesia has utilized their wastewater to produce methane and organic fertilizer, but SMEs still discharged directly into environment. One of the industrial centers of alcohol located in Polokerto district, Sukoharjo regency, Central Java province. So far, almost all of the existing alcohol SMEs in Polokarto region discharge their wastewater directly to local irrigation channel towards Samin river. It makes water in irrigation channels unfit for use, even contaminate the well water that people use for cooking and washing [18].

In other hand, SMEs can utilize alcohol waste into bioenergy sources as an alternative energy sources as well as prevent environmental problems.

\section{Method}

This review summarizes field study of ethanol production, vinasse characteristics and production in Polokarto center, and literatures study on vinasse treatments and potential usages. Experience in treating organic wastewater, especially Palm Oil Mill Effluent (POME) into biogas as energy gives contribution in thought in vinasse treatment. Design of Fixed Dome High Rate Anaerobic Reactor (FDHRAR) is used as a model to convert vinasse into biogas. aims to expand the 
contact area between the substrate and microbial with modification of the substrate flow system and the area of the filter and integrate with the gas accumulator.

Primary attention is focused on the calculation of bioenergy potential obtained from digestion vinasse to methan.

\section{Results and discussion}

\subsection{Characterization of vinasse}

Vinasse is the residual remaining from the fermentation and distillation of alcoholic liquors. (Merriam-Webster Dictionary). Characteristic of vinasse SMEs in Polokarto are summarized in table 1.

Table 1. Typical characteristic of Polokarto vinasse

\begin{tabular}{|l|l|l|l|}
\hline No & Parameter & Unit & Concentration \\
\hline 1 & $\mathrm{BOD}_{5}$ & $\mathrm{mg} / \mathrm{l}$ & 109,038 \\
\hline 2 & $\mathrm{COD}$ & $\mathrm{mg} / \mathrm{l}$ & 353,797 \\
\hline 3 & $\mathrm{TSS}$ & $\mathrm{mg} / \mathrm{l}$ & 7,200 \\
\hline 4 & $\mathrm{pH}$ & - & $4-6$ \\
\hline 5 & Temperature & ${ }^{\circ} \mathrm{C}$ & $40-50$ \\
\hline
\end{tabular}

There are about 115-150 business units SMEs in Polokarto center, produce an average of $1 \mathrm{~m} 3$ alcohol per day each units from $4 \mathrm{~m} 3$ fermented molasses. It is much smaller than distillery industry in India, which is reaches 1 : 4-10 L molasses [8]. The result of analysis of vinasse in table 1 , the organic content is very high, look at the parameters of BOD and COD. The summarized that the waste water of vinasse is potential as renewable energy source from biomass.

In general equation the reaction of methane formation as follow [19] :

$$
\begin{aligned}
& \mathrm{C}_{\mathrm{x}} \mathrm{H}_{\mathrm{y}} \mathrm{O}_{2}+(\mathrm{x}-1 / 4 \mathrm{y}-1 / 2 \mathrm{z}) \mathrm{H}_{2} \mathrm{O} \\
& \text { z) } \mathrm{CO}_{2}+(1 / 2 \mathrm{x}-1 / 8 \mathrm{y}+1 / 4 \mathrm{z}) \mathrm{CH}_{4}
\end{aligned} \longrightarrow(1 / 2 \mathrm{x}-1 / 8 \mathrm{y}+1 / 4
$$

\subsection{Treatment by Modified of FDHRAR}

BBTPPI has developed the Fixed Dome High Rate Anaerobic Reactor (FDHRAR) that has been applied in the palm oil industry [19]. The reactor is designed to produce bioenergy with the innovation of contact expansion between substrate and microorganism, to $30 \%$ filter volume. It would lead to increase the degree of degradation of complex compounds into simple organic compounds with a faster residence time (designed around 10-15 days). Calculated efficiency of COD removal will increase around 74,97\% and bioenergy production increased with the content of $\mathrm{CH}_{4}$ reached $47,5 \%$.

Development of FDHRAR by filter addition with innovation reactor integration model Fixed DomeHybrid Anaerobic Filter aims to expand the contact area between the substrate and microbial with modification of the substrate flow system and the area of the filter around $60-70 \%$ and integrate with the gas accumulator to accommodate and regulate the flow of bioenergy production, thus minimizing the loss or "losses" of the biogas produced, and improve production efficiency, controlling the effects of gases and global warming.

It is in accordance with the opinion of Borja R, Banks CL and Sanches E, [20] that anaerobic treatment aimed to accumulating and utilizing the reformed gas must be performed on a reactor that has a special shape instead of an open pool as it is today.

Figure 1 is a picture of Fixed Dome Hybrid Anaerobic Filter technology innovation model of bioenergy generator from raw material of industrial waste of ethanol.

Through this modification, the efficiency of bioenergy production from alcohol waste will increase from $47.56 \%$ [19] become more than $50 \%$, and the decrease in COD load can increase from about $74.97 \%$ become more than $85 \%$. Hydraulic retention time will be shorter from 10-15 days to 6-8 days.

Seeing the characteristic properties of the waste water alcohols having organic content higher, then the stored energy potential of biomass is high, so before it is processed in the WWTP needs to discover the potential of this energy by passing on a reactor biogas digester to accumulate and utilize gases.

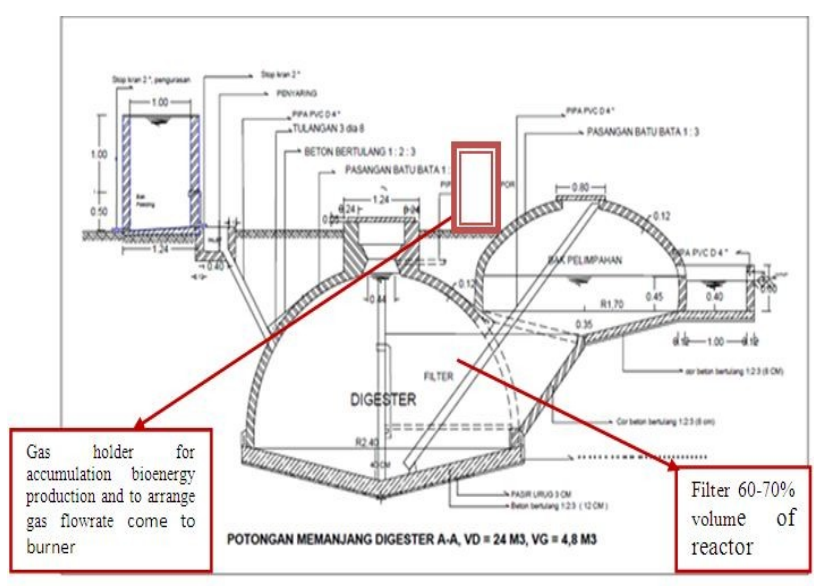

Fig. 1. Rector Design for the process of Vinasse Digestion

\subsection{Bioenergy potential}

Considering the characteristic properties of the vinasse with high organic content, it is necessary to extract the energy potential by passing it on a biogas digester reactor to accumulate and utilize the anaerobic reform gas before being processed in WWTP. As a fuel that has a high enough calorific value and the number is quite a lot.

According to Benefield, Larry.H [21] on each $1 \mathrm{~kg}$ reduction of $\mathrm{COD}$ in the anaerobic process will produce 350 liters of methane (CH4). The reshuffle process will reduce the COD value by $80-90 \%$, so the next processing will be lighter load, and reduce the need for land.

Assumption of $75 \%$ COD is processed per day, then the potential of methane production in Polokarto's 
alcohol industry center is $307,045 \mathrm{~m} 3$ / day. If the calorific value of biogas approximately 4,500 - 6,300 $\mathrm{kcal} / \mathrm{m} 3$, it will get energy of $1.381 .703-1934.383 .5$ $\mathrm{kcal} /$ hari.

The average energy requirement in the distillation process is $2700 \mathrm{kcal} / \mathrm{l}$ of alcohol production [22](Navarro, Del C. Sepúlveda, \& Rubio, 2000) so that the resulting bioenergy will be used to produce alcohols of approximately 511.7-716.4 m3.

It is expected that the bioenergy gained from the process of alcohol waste digestion can be used again as a renewable alternative energy in the process of separation (distillation). The separation process is the most energyintensive process [22] and currently the energy used is firewood. Decreased availability of timber is currently in line with the decreasing forest area due to changing land use.

The scarcity and high price of firewood make the craftsmen start to switch to LPG fuel, but because LPG price is increasing every day it makes many craftsmen close their business. Looking at the energy potential contained in large biogas (theoretical calculations), the resulting bioenergy can be utilized as a renewable energy source (EBT) for use in the continuous separation / distillation process in the alcohol industry

From the use of such raw materials, the volume of waste generated by $2.7 \mathrm{~m} 3$ / industry / day x 150 industries, the amount of waste generated by industrial alcohol centers amounts to approximately $405 \mathrm{~m} 3$ / day. The quality of wastewater produced has BOD5 = $109.038 \mathrm{mg} / 1, \mathrm{COD}=353.797 \mathrm{mg} / 1$ and $\mathrm{TSS}=7200$ $\mathrm{mg} / 1$ (BBTPPI, 2016). From these characteristics both in quality and quantity, industrial waste of alcohol is very potential to be used as raw material of biogas (bioenergy) energy sources (source: initial assessment of BBTPPI industry team).

\section{Conclusion}

Liquid vinasse wastes generated from the industrial production process of alcohol have high organic content, large amount and continuous production, so it is potential as raw material for anaerobic digestion process to produce renewable energy source from sustainable biomass (bioenergy).

The digestion process is carried out in a specially designed reactor with innovative Fixed Dome Hybrid Anaerobic Filter technology that will produce optimal bioenergy with fast retention time and impact on land use savings.

The company will get added value from renewable bioenergy sources that can substitute on other energy usage at factory operations.

The surrounding environment will become cleaner and healthier control of greenhouse gases and global warming.

\section{Acknowledgments}

Acknowledgments are shared with colleagues of the BBTPPI especially water laboratory Semarang, who have assisted in field surveys, sampling and analyzing the characteristics of vinasse.

\section{References}

1. A. Hidayat, Indonesia terancam krisis energi (2016) Retrieved from https://m.tempo.co/read/news/2016/05/24/0907736 60/pada-2020-2030-indonesia-terancam-krisisenergi

2. Pusat Komunikasi Publik Kementerian Perindustrian. (2015). Rencana Induk Pembangunan Industri Nasional 2015 - 2035.

3. G. J. Sheehan and P. F. Water Research, 14, 257277 (1980)

4. S. Mohana, B. K. Acharya, D. Madamwar, Journal of Hazardous Materials, 163, 12-25 (2009)

5. S. R. Lekshmi, IJEEM, 4(4), 339-344 (2013)

6. S. Ayub and S. Usmani, IJRET, 3 (2), 204-214 (2014).

7. M.P. Wags and P. D. Nemade, IJIRAE, 2, 30-40 (2015)

8. D. Ariyanti and H.Hadiyanto, Bulletin of Chemical Reaction Engineering and Catalysis, 7(3), 179-184 (2013)

9. H.Hadiyanto, D. Ariyanti, A.P.Aini, D.S.Pinundi, Energy Procedia, 47,108-112(2014)

10. X. L. Melamane, P. J. Strong and J. E. Burgess, S. Afr. J. Enol. Vitiv, 28, 1, 25-35 (2007)

11. H. Harada, S. Uemura, A. C. Chen and J. Bioresource Technology, 55 , 215-221 (1996)

12. B. Wolmarans, and G. H. De Villiers, Water SA, 28(1), 63-68 (2002)

13. W. P. Barber, and D. C. Stuckey, Wat. Res. 33, 7, 1559-1578 (1999).

14. M. L. Tansengco, D. L. Herera, J. C. Tejano. eJBio, 12(4), 367-373 (2016)

15. Z. V. P. Murthy \& L. B. Chaudari, Global NEST Journal. 11,2, 235-240 (2009)

16. A. Kadam, and K. Upahdhyay. Jr. Of Industrial Pollution Control, 28(1),51-56 (2012)

17. Wicaksono, B. E. (2016). Tercemar Limbah Ciu, Kali Samin Sukoharjo Hitam Pekat Sukoharjo. Retrieved from http://www.solopos.com/ 2016/10/31/tercemar-limbah-ciu-kali-saminsukoharjo-hitam-pekat-764880

18. N. Harihastuti and B. Marlena, Proceeding of Energy Seminar, UNDIP (2016)

19. R. Borja, C. L. Banks, and E. Sanches, Jurnal of Biotechnology, 45, 125-135 (1996)

20. L. D. Benefild, and C. W. Randal, Prentice Hall Inc. Englewood Clifts (2001)

21. A.R. Navarro, M. D. C. Sepulveda and M.C. Rubio, Waste Management, 20 (7), 581-585 (2000) 